\title{
Mentoring program and its impact on individuals' advancement in the Malaysian context
}

\author{
Azman Ismail ${ }^{1}$, Muhammad M. Abdullah², Sebastian K. Francis ${ }^{3}$ \\ ${ }^{1}$ Universiti Malaysia Sarawak (MALAYSLA); ${ }^{2}$ Universiti Teknologi Malaysia International \\ Campus (MALAYSLA); ${ }^{3}$ University Tunku Abdul Rabman (MALAYSLA) \\ iazman@ffs.unimas.my; mubdmadi@ic.utm.my; seb28koren@yahoo.com
}

Received November 2009

Accepted December 2009

\begin{abstract}
The literature on workplace training highlights that the mentoring program is an important employee development method practiced in successful organizations. The ability of mentors either informally or formally to implement the mentoring program activities may lead to higher individuals' psychosocial support and career development. The nature of this relationship is interesting, but the role of the mentoring program as a predicting variable of individuals' advancement (psychosocial support \& career development) has been given less attention in mentoring program models especially in the Malaysian organizational context. Therefore, this study was conducted to examine the direct effect of a mentoring program on individuals' advancement using a 153 usable questionnaire gathered from employees who have worked in a public university in East Malaysia. The outcomes of regression analysis showed four important findings: Firstly, formal mentoring positively and significantly correlated with individuals' psychosocial support. Secondly, informal mentoring positively and significantly correlated with individuals' career development. Thirdly, formal mentoring positively and significantly correlated with individuals' career development. Fourthly, informal mentoring positively and significantly correlated with individuals' psychosocial support. The results have empirically confirmed that properly implemented mentoring programs can lead to increased individuals' advancement in the studied organization. In addition, implications and discussions are also elaborated.
\end{abstract}


Keywords: formal mentoring, informal mentoring, career development, psychosocial support, Malaysia.

\section{Introduction}

In ancient Greek literature, mentoring was first highlighted in the epic story of 'The Odyssey' written by Homer. In this story, Odysseus told his loyal and experienced friend, Mentor, (a person of great wisdom and trustworthiness) to teach his son, Telemachus, (a mentee or protégé with less experience) about the tips of handling challenging lifestyles before he left for the Trojan War (Edlind \& Haensly, 1985; Merriam, 1993). Based on this story, mentoring was traditionally viewed as an important field of education (Johnson et al., 1991) and/or counseling (Gregson, 1994), where a mentor was regarded as an old man who possessed wisdom and could be trusted to educate young men who had little experience (J ohnson et al., 1991; Kram, 1985; Russell \& Adams, 1997; Wanguri, 1996). Later, this inspired organizational development (OD) scholars to generally interpret the concept and practice of mentoring programs in line with the development of organizations in the current era of globalization (Dennison, 2000; Northcott, 2000; Oliver \& Aggleton, 2002).

In an organizational context, mentoring is often viewed as a training and development (T\&D) program that can be used to increase a group's and/or individuals' potentials to carry out particular duties and responsibilities, to familiarize with new techniques, and care all aspects of the mentees (Hanford \& Ehrich, 2006; Johnson et al., 1991; Long, 2002). Mentoring is also viewed as integral to learning in the workplace, to receiving career help, and for developmental and psychosocial support (Johnson et al., 1991; Long, 2002; Cummings \& Worley, 2009). Mentoring models vary according to different organizational context and there is no one best model to fit the needs of all organizations (Ismail et al., 2009; Irving et al., 2003). They have to be specially designed and administered based on the differences and uniqueness of an organization in terms of beliefs, values, orientations, stress, strengths and weaknesses (Hawkey, 1997; Irving et al., 2003; Ritchie \& Conolly, 1993; Ritchie \& Genoni, 1999). These factors have affected the implementation of mentoring type as to whether formal and/or informal mentoring activities should be implemented 
in a particular organization (Chao et al., 1992; Murray, 1991; Ragins \& Cotton, 1993, 1999).

A formal mentoring program is often viewed as the structured and coordinated relationship between mentor and mentee, using standard norms, continuous action plans, time frame, and particular objectives (Bahniuk \& Hill, 1998; Hansford et al., 2003; Noe et al., 2002). Specifically, this mentoring program has salient characteristics: first, the mentor is defined as a more knowledgeable and experienced person (e.g., senior staff) whereas the mentee is defined as a less knowledgeable and less experienced person (e.g., junior staff) (Kram, 1985; Dreher \& Cox, 1996; Noe et al., 2002). Second, mentors should act as role models, teachers, sponsors, encouragers, counselors, and be a friend to mentees in order to increase the individuals' new knowledge, update skills and imbue positive attitudes (Anderson \& Shannon, 1988; Kram, 1985; Levinson et al., 1978). Third, they are regularly assigned to encourage group and/or individual activities within a defined period of time (Ritchie \& Connolly, 1993; Ritchie \& Genoni, 1999).

Conversely, informal mentoring is often seen as the process and systems of relationship between mentors and mentees to achieve specific demands and extemporizations. A mentoring program is widely implemented to complement and strengthen formal mentoring programs (Goldstein \& Ford, 2002; Ragins, 1997, 1999). Moreover, according to Hansman (2000), informal mentoring relationships are dependent on the relationship developed between the mentor and mentee, and these relationships may last for many years. In informal mentoring relationships, mentors and mentees choose with whom he or she may want to work. If both mentoring programs are properly managed and effectively implemented they may lead employees to achieve organizational strategies and goals (Friday \& Friday, 2002; Khian Jui et al., 2009; Lindenberger \& Zachary, 1999; Irving et al., 2003).

Surprisingly, extant research in this area show that the ability of managers to properly design and administer mentoring programs may have a significant impact on individuals' career development and psychosocial support (Allen et al., 2005; Hegstad \& Wentling, 2005; Niehoff, 2006; Okurame \& Balogun, 2005). Many scholars, such as Kram (1985), Kram and Bragar (1991), Baugh and Scandura (1999), Hunt and Michael (1983) and Ragins and Cotton (1999) highlight that career development is often viewed as helping individuals to acquire the skills and experiences needed to perform current and future jobs, give advice, increase the 
ability of individuals to positively influence others, and protect individuals' dignities from being affected by negative environments. Whilst, psychosocial support is often seen as helping individuals in building confidence, overcoming pressures and strains, assisting their personal life, getting opinions heard and valued, sharing dreams, providing feedback, creating awareness of contribution to relationship, and teaching with examples (Kram, 1985; Kram \& Bragar, 1991; Lyon et al., 2004; Ritchie \& Genoni, 1999; Russell \& Adams, 1997). In a mentoring program model, many scholars think that the ability of mentors and mentees to use comfortable interactional styles, such as communication openness, respect, accountability, honesty and active participation may lead to increased individuals' career development and psychosocial support (Scandura, 1992; Chao et al., 1992; Ragins $\&$ Cotton, 1993, 1999).

In both formal and informal mentoring relationships, two key aspects that are essential to mentoring relationships in organizations are the psychosocial support and career development related functions (Kram, 1988). Even though numerous studies have been carried out, little is known about the effectiveness of a mentoring program as a predicting variable in mentoring program literature (Khian Jui et al., 2009; Niehoff, 2006; Okurame \& Balogon, 2005). Many scholars had revealed that the role of mentoring programs were less emphasized because previous studies had highlighted the features of informal and formal mentoring activities, as well as their suitability in different organizational contexts (Friday \& Friday, 2002; Hansford et al., 2003; Irving et al., 2003). The findings of such studies have not been substantial enough to help theorists and practitioners to understand the influence of mentoring type on individuals' personal advancement (Niehoff, 2006; Okurame \& Balogun, 2005; Khian Jui et al., 2009).

The study is conducted to examine four major objectives: firstly, the effect of formal mentoring on individuals' career development. Secondly, the effect of formal mentoring on individuals' psychosocial support. Thirdly, the effect of informal mentoring on individuals' career development. Finally, the effect of informal mentoring on individuals' psychosocial support. The study was conducted in a public university in East Malaysia and for ethical reasons the name of the targeted organization is kept confidential. 


\section{Literature review and research hypotheses}

\subsection{Context of the study}

In the selected organization, mentoring programs are segments of human resource development (HRD) that have consistently and continuously been implemented since 1993 to support the organizational vision to become an exemplary university of internationally acknowledged stature and a scholarly institution of choice. These mentoring programs were informally and formally implemented at both nonacademic and academic faculties.

In order to understand the nature of a mentoring program, in-depth interviews were conducted involving two members of the human resource (HR) staff and two members of the academic staff during and before the pilot study. Information gathered from those interviews showed that mentors were management employees and senior employees whereas the mentees comprised supporting staff and junior staff. Formal mentoring was done through group discussions (i.e., department and teamwork meetings, counseling sessions, and performance appraisal sessions) during office hours at the workplace. Informal mentoring was frequently implemented through individual discussions (i.e., seeking advice, personal meetings and gatherings) after office hours inside and/or outside the workplace. In those interactions, mentors often related with mentees through communication openness. Participation styles were used as major instruments to deliver messages, share knowledge and experiences, encourage teamwork and promote collective decisions in mentoring programs. Those practices may lead to enhance individuals' career development and psychosocial support in the workplace. Although relationships were established, little was known about the role of mentoring style as a predicting variable in the mentoring program model of the chosen organization in the Malaysian organizational context (Khian Jui, 2008). Therefore, further investigation about the issue was necessary and imperative.

\subsection{Relationship between mentoring program and individuals' advancement}

A mentoring relationship refers to a dyadic relationship between a more experienced member (senior) of the organization and with a less experienced individual (junior). A mentor provides support to a mentee and acts as a role model and is important for organizational development. Mentoring relates 
workplace learning and leadership principles in career development and psychosocial support.

Most previous studies used a direct effect model to investigate general mentoring programs in Western organizational framework with different respondents, such as 510 first-line bank managers (Okurame \& Balogun, 2005), and 194 practising veterinarians (Niehoff, 2006). Those studies found that properly implemented formal and informal mentoring program activities (e.g., friendship, social support, role modelling, acceptance and participation) had been a determinant of individuals' advancement, such as career development and psychosocial support (Niehoff, 2006; Okurame \& Balogun, 2005). The availability of mentoring programs pertaining to relationships was linked to career development (Scandura, 1992) and to higher wages and fast-tracked career advancement (Dansky, 1996).

Those findings were consistent with the notion of organizational behaviour theory (Byrne and Griffitt,1973); whose similarity-attraction paradigm and Bowlby's (1969) attachment theories stated that individuals who practiced good interactional styles in planning and administering activities might affect individuals' advancement, especially in career development and psychosocial support (Bowlby, 1969; Byrne \& Griffitt, 1973; Turban et al., 2002; Young et al., 2006). Specifically, similarity-attraction paradigm (Byrne \& Griffitt, 1973) explicitly highlighted that the integration of similarity, attractiveness and likings were important determinants of effective human relationships in the workplace (Berscheid, 1994; Sprecher, 1998). The application of that theory in a mentoring program model showed that individuals could do work in a cooperative fashion, communicate openly and clearly and interact on social issues positively. Consequently, it motivated mentees' perceptions that they had similar values as their mentors such as high satisfaction and had a close rapport with them.

As a result, it may lead to increased individuals' advancement in regards to career development and psychosocial support (Ragins et al., 2000; Hegstad \& Wentling, 2005; Turban et al., 2002). The Attachment Theory (Bowlby, 1969) found that the ability of individuals to develop and maintain a relationship began at a very early stage and was influenced by attachment feelings towards parents or the primary caretaker. In relation to a mentoring program, the theory may be used to explain how and why some mentors and mentees felt more comfortable to maintain a professional relationship and/or develop a personal bond (Ainsworth et al., 1978; 
Young et al., 2006). The application of the theory in a mentoring program framework showed that the comfortable interaction between mentors and mentees who have the same and/or different personality backgrounds would positively motivate mentees' perceptions of their feelings of high security, trust and sense of belonging in mentoring activities. Consequently, it might enhance the individuals' advancement, especially in career development and psychosocial support (Allen \& Eby, 2004; Hegstad \& Wentling, 2005; Young et al., 2006).

The literature reviewed was used as the basis in developing a conceptual framework for the current study as shown in Figure 1.

Independent variable (Mentoring program)

\begin{tabular}{|l|l|l|}
\hline $\begin{array}{l}\text { Formal } \\
\text { mentoring } \\
\text { Informal } \\
\text { mentoring }\end{array}$ & & $\begin{array}{l}\text { Career } \\
\text { development }\end{array}$ \\
\cline { 2 - 4 } & & $\begin{array}{l}\text { Psychosocial } \\
\text { support }\end{array}$ \\
\hline
\end{tabular}

Figure 1. "Conceptual model of the relationship between mentoring programs and individuals' advancement". Source: authors

Based on the framework, it seems reasonable to assume that properly implemented informal and formal mentoring activities will influence career development and psychosocial support among the employees of the selected organization. This practice has been shown to influence Western employees. Further, organizational behavioral theory suggests that properly implemented formal and informal mentoring activities in job performance can lead to higher individuals' career development and psychosocial support in organizations. Therefore, it is hypothesized that:

- $\mathrm{H} 1$ : There is a positive relationship between formal mentoring and individuals' career development.

- $\mathrm{H} 2$ : There is a positive relationship between formal mentoring and individuals' psychosocial support.

- H3: There is a positive relationship between informal mentoring and individuals' career development. 
- H4: There is a positive relationship between informal mentoring and individuals' psychosocial support.

\section{Methodology}

This study used a cross-sectional research design that allows the researchers to integrate literature review, in-depth interviews, pilot study and survey questionnaires as a major procedure to gather data. As supported by many researchers, the use of such methods may gather accurate and less bias data (Cresswell, 1998; Sekaran, 2000) and it allows the researcher to create differences among the variables studied.

At the initial stage of data collection, in-depth interviews were conducted involving four experienced employees, namely two experienced members of the human resource (HR) staff, and two experienced members of the academic staff employed in the chosen organization. They were selected based on a purposive sampling where the selected employees had a working experience of more than seven years in the organization. Information gathered from such employees helped the researchers to understand the nature of the mentoring program, individuals' career and psychosocial characteristics, as well as the relationship between such variables in the studied organization.

After refining, categorizing and comparing the information with the related literature review, the triangulated information was used as a guideline to develop the content of a survey questionnaire for a pilot study. Next, the pilot study was conducted by discussing the questionnaire with four employees who worked in the organization. Their feedback was used to verify the content and format of the questionnaire for an actual survey. Back translation technique was used to translate the content of the questionnaire both in Malay and English in order to increase the validity and reliability of the instrument (Hulland, 1999; Van Maanen, 1983).

The survey questionnaires have four sections. Firstly, formal mentoring had a 4item scale developed based on the formal mentoring literature (Allen \& Eby, 2004; Blake-Beard, 2001; Bisk, 2002; Hansford \& Ehrich, 2006; Hansford et al., 2003). Secondly, informal mentoring had a 5 -item scale developed based on the informal mentoring literature (Allen et al., 2005; Bisk, 2002; Chao et al., 1992; Kram, 
1985; Kram \& Bragar, 1991; Ragins \& Cotton (1993, 1999). Thirdly, psychosocial had a 4-item scale developed based on the employee psychosocial literature (Noe, 1988; Levesque et al., 2005; Ritchie \& Connolly, 1993; Ritchie \& Genoni, 1999; Waters, 2004). Finally, career had a 4-item scale developed based on the workplace career literature (Allen \& Eby, 2004; Hegstad \& Wentling, 2005; Levesque et al., 2005; Ragins et al., 2000). All items were measured using a 7item Likert scale ranging from 'very strongly disagreed/dissatisfied' (1) to 'very strongly agreed/satisfied' (7). Demographic variables were used as controlling variables (i.e., gender, age, education, length of service, position and division) because this study focused on employee attitudes. The items used in the actual survey questionnaire are shown in Table 2.

The population for this study was all 1456 employees in the selected organization. In the data collection process the human resource (HR) manager did not provide a list of registered employees and did not allow the researchers to directly distribute copies of the survey questionnaire to employees who worked in the organization. After considering this situation, a quota sampling was used to determine the number of respondents based on the duration of the study and budget constraints, which numbered 200 employees. Besides, a convenient sampling technique was opted for in distributing the survey questionnaire to employees because the researchers did not choose the respondents randomly. Therefore, the 200 copies of the survey questionnaire were distributed to employees who were willing to take part in the exercise through the good offices of the assistant HR manager, supervisors and/or heads of department/unit in the organization. Of the number, 153 sets of usable questionnaire were returned to the researchers, yielding a 76.5 percent response rate. The survey questionnaire was answered by participants based on consensus and voluntary basis. A Statistical Package for Social Science (SPSS) version 15.0 was used to analyze the validity and reliability of the measurement scales and thus tested the four research hypotheses of the study.

Firstly, exploratory factor analysis (EFA) was used to assess the validity and reliability of the measurement scales (Hair et al., 1998; Nunally \& Bernstein, 1994). Relying on the guidelines set up by these statisticians, a factor analysis with direct oblimin rotation was first done for all the items that represented each research variable, and this was followed by confirmatory factor analysis (CFA), that is, Kaiser-Mayer-Olkin Test (KMO), Bartlett's test of sphericity (BTS), eigenvalue, 
variance explained and Cronbach alpha (a). Variables that met the acceptable standard of validity and reliability analyses were used in testing the hypotheses.

Secondly, Pearson correlation ( $r$ ) analysis and descriptive statistics were employed to analyze the constructs and the usefulness of the data set (Tabachnick et al., 2001; Yaacob, 2008). Finally, stepwise regression analysis was utilized to test the direct effect model because it could assess the magnitude of each independent variable, and the relationship between many independent variables (IVs) and one dependent variable (DV). Standardized coefficients (standardized beta weights) were used to show the results of relationship between each independent variable and dependent variable. Based on the value of standardized beta $(\beta)$, the results determined which independent variables were dominant in affecting the dependent variable (Baron \& Kenny, 1986; Foster et al., 1998; Jaccard et al., 1990).

\section{Findings}

Table 2 shows that most of the respondents were female ( 57.5 percent), male supervisors (56.9 percent), aged between 21 to 30 years (46.4 percent), STPM/Diploma holders (33.3 percent), staff who served less than 5 years (54.9 percent), non-academic staff (58.2 percent), and employees who worked in the academic department (53.6 percent).

\begin{tabular}{|c|c|c|}
\hline Gender (\%) & Age (\%) & Length of Service $(\%)$ \\
\hline Male $=42.5$ & 21 to 30 years old $=46.4$ & 0 to 5 years $=54.9$ \\
\hline Female $=57.5$ & 31 to 40 years old $=39.2$ & 6 to 10 years $=22.2$ \\
\hline Supervisor's Gender (\%) & 41 to 50 years old $=9.8$ & 11 to 15 years $=13.7$ \\
\hline Male $=56.9$ & More than 51 years old $=4.6$ & More than 16 years $=9.2$ \\
\hline Female $=29.4$ & Academic Qualification (\%) & Position (\%) \\
\hline Male and Female $=13.7$ & $\mathrm{PMR}=0.7$ & Academic Staff $=41.8$ \\
\hline (More than one Supervisor) & $S P M=22.9$ & Non-Academic Staff $=58.2$ \\
\hline & STPM/Diploma=33.3 & Division (\%) \\
\hline & Bachelor Degree $=15.0$ & Academic \\
\hline & Masters Degree $=18.3$ & Department $=53.6$ \\
\hline & $\mathrm{PhD} /$ Doctor & Non-Academic \\
\hline & of Philosophy=9.8.8 & Department $=46.4$ \\
\hline \multicolumn{3}{|l|}{ Note: } \\
\hline \multirow{2}{*}{\multicolumn{3}{|c|}{$\begin{array}{l}\text { PMR } \\
\text { SPM/MCE }\end{array}$}} \\
\hline & & \\
\hline STPM & 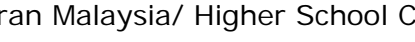 & \\
\hline
\end{tabular}

Table 1. "Respondent characteristics". Source: authors

Table 2 and Table 3 show the results of the validity and reliability analyses for all the measurement scales used in this study. A factor analysis with direct oblimin rotation was first carried out for four main variables with 17 items. After that, 
Kaiser-Mayer-Olkin Test (KMO), a measure of sampling adequacy, was conducted for each variable and the results indicated that it was acceptable. Relying on Hair et al. (1998), and Nunally and Bernstein's (1994) guideline, these statistical analyses showed that: (1) the value of factor loadings for all items that represented each research variable was 0.5 and more (Hair et al., 1998), indicating the items met the acceptable standard of construct validity analysis; (2) all research variables exceeded the acceptable standard of Kaiser-Meyer-Olkin's value of 0.6, were significant in Bartlett's test of sphericity; (3) all research variables had eigenvalues larger than 1; and (4) all research variables exceeded the acceptable standard of reliability analysis of 0.70 (Nunally \& Bernstein, 1994). These statistical results confirmed that the measurement scales met the acceptable standard of validity and reliability analyses.

\begin{tabular}{|c|c|c|c|c|c|}
\hline \multirow[t]{2}{*}{ Variable } & \multirow[t]{2}{*}{ I tem } & \multicolumn{4}{|c|}{ Component } \\
\hline & & 1 & 2 & 3 & 4 \\
\hline $\begin{array}{l}\text { Formal } \\
\text { mentoring }\end{array}$ & $\begin{array}{l}\text { 1.I prefer to have a say in formal discussions } \\
\text { 2.Participation in formal discussions is a good } \\
\text { mechanism to overcome daily job problems } \\
\text { 3.Participation in formal discussions helped to } \\
\text { improve my confidence in the workplace } \\
\text { 4.Participation in formal discussions is } \\
\text { important for sharing ideas }\end{array}$ & & & $\begin{array}{l}.76 \\
.87 \\
.86 \\
.82\end{array}$ & \\
\hline $\begin{array}{l}\text { Informal } \\
\text { mentoring }\end{array}$ & $\begin{array}{l}\text { 1.I prefer to have a say in informal } \\
\text { discussions } \\
\text { 2. Participation in informal discussions is a } \\
\text { good mechanism for overcome daily job } \\
\text { problems } \\
\text { 3. Participation in informal discussions helped } \\
\text { to improve my confidence in the workplace } \\
\text { 4. Participation in informal discussion is } \\
\text { important for sharing ideas } \\
\text { 5.I think that informal gathering helped to } \\
\text { enhance a sense of belonging among } \\
\text { workers }\end{array}$ & & $\begin{array}{l}.80 \\
.73 \\
.84 \\
.86 \\
.81\end{array}$ & & \\
\hline $\begin{array}{l}\text { Psychosocial } \\
\text { Support }\end{array}$ & $\begin{array}{l}\text { 1. My immediate boss/supervisor acted as a } \\
\text { good role model for me } \\
\text { 2. My immediate boss encouraged me to try } \\
\text { new ways of behaving in doing my job } \\
\text { 3.I respect and admire my immediate boss } \\
\text { 4. My immediate boss/supervisor } \\
\text { encouraged me to talk openly about anxiety } \\
\text { and fears in the workplace }\end{array}$ & $\begin{array}{l}.64 \\
.85 \\
.86 \\
.86\end{array}$ & & & \\
\hline $\begin{array}{l}\text { Career } \\
\text { development }\end{array}$ & $\begin{array}{l}\text { 1. My immediate boss provided specific } \\
\text { guidance for achieving my career goals } \\
\text { 2. My immediate boss gave me assignments } \\
\text { that prepared me for a higher position } \\
\text { 3. My immediate boss suggested specific } \\
\text { strategies to accomplish work objectives } \\
\text { 4. My immediate boss/supervisor exchanged } \\
\text { experiences with me to improve job } \\
\text { problems in the workplace }\end{array}$ & & & & $\begin{array}{l}.88 \\
.57 \\
.73 \\
.64\end{array}$ \\
\hline
\end{tabular}

Table 2. "Measurement Scales". Source: authors 


\begin{tabular}{|l|c|c|c|c|c|c|c|}
\hline \multicolumn{1}{|c|}{ Measure } & Items & $\begin{array}{c}\text { Factor } \\
\text { Loading } \\
\text { S }\end{array}$ & KMO & $\begin{array}{c}\text { Bartlett's } \\
\text { Test of } \\
\text { Sphericity }\end{array}$ & $\begin{array}{c}\text { Eigen- } \\
\text { value }\end{array}$ & $\begin{array}{c}\text { Variance } \\
\text { Explained } \\
(\%)\end{array}$ & $\begin{array}{c}\text { Cronbach } \\
\text { Alpha }\end{array}$ \\
\hline Formal mentoring & 4 & $.76-.87$ & .80 & $\begin{array}{c}389.78, \\
\mathrm{p}=0.000\end{array}$ & 2.95 & 73.79 & .88 \\
\hline $\begin{array}{l}\text { Informal } \\
\text { mentoring }\end{array}$ & 5 & $.73-.86$ & .78 & $\begin{array}{c}455.91, \\
\mathrm{p}=0.000\end{array}$ & 3.47 & 69.49 & .89 \\
\hline $\begin{array}{l}\text { Psychosocial } \\
\text { Support }\end{array}$ & 4 & $.64-.86$ & .84 & $\begin{array}{c}380.94 .0, \\
\mathrm{p}=0.000\end{array}$ & 3.08 & 77.08 & .90 \\
\hline $\begin{array}{l}\text { Career } \\
\text { Development }\end{array}$ & 4 & $.57-.88$ & .82 & $\begin{array}{c}319.30, \\
\mathrm{p}=0.000\end{array}$ & 2.93 & 73.19 & .88 \\
\hline
\end{tabular}

Table 3. "The validity and reliability analyses for measurement scales". Source: authors

Table 4 shows the results of Pearson correlation analysis and descriptive statistics. Means for all variables were between 5.0 and 5.6, signifying the levels of formal mentoring, informal mentoring, career, and psychosocial ranging from high (4.0) to highest level (7.0). The correlation coefficients for the relationship between the independent variable (i.e., formal mentoring and informal mentoring) and the dependent variable (i.e., career and psychosocial) were less than 0.90 , indicating the data were not affected by any serious collinearity problem (Hair et al., 1998).

\begin{tabular}{|l|c|c|c|c|c|c|}
\hline \multicolumn{1}{|c|}{ Variable } & Mean & $\begin{array}{c}\text { Standard } \\
\text { Deviation } \\
\text { (SD) }\end{array}$ & \multicolumn{4}{|c|}{ Pearson Correlation Analysis } \\
\hline & & & 1 & 2 & 3 & 4 \\
\hline 1. Formal mentoring & 5.6 & 0.98 & 1.00 & & & \\
\hline 2. Informal mentoring & 5.3 & 1.08 & $0.30^{* *}$ & 1.00 & & \\
\hline $\begin{array}{l}\text { 3. Psychosocial } \\
\text { Support }\end{array}$ & 5.2 & 1.14 & $0.48^{* *}$ & $0.33^{* *}$ & 1.00 & \\
\hline 4. Career development & 5.0 & 1.10 & $0.42^{* *}$ & $0.50^{* *}$ & $0.70^{* *}$ & 1.0 \\
\hline
\end{tabular}

Note: Significant at $* 0.05 ; * * 0.01$

Table 4. "Pearson correlation analysis and descriptive statistics". Source: authors

Table 5 shows that the demographic variables were entered in Step 1 and then followed by entering the independent variable in Step 2. Psychosocial support was used as the first dependent variable. An examination of multicollinearity in the coefficients table showed that the tolerance value for the relationship between formal mentoring and psychosocial support was 0.91 , and the tolerance value for the relationship between informal mentoring and psychosocial support was 0.97. The tolerance values were more than the established tolerance value of 0.20 (as a rule of thumb), indicating the variables were not affected by multicollinearity problems (Fox, 1991; Tabachnick et al., 2001).

Hence, Table 5 shows the results of regression analysis that were summarized in the two steps. In step 1 , age and length of service was found to be a significant predictor of psychosocial support ( $\beta=-0.27, p<0.05 ; \quad \beta=0.28, \quad p<0.05$, 
respectively), accounting for 9 percent of the variance in the dependent variable (psychosocial support). Step 2 showed that the formal mentoring positively and significantly correlated with psychosocial support $(\beta=0.39, p<0.001)$, and informal mentoring also positively and significantly correlated with psychosocial support ( $\beta=0.18, p<0.05$ ), therefore $\mathrm{H} 1$ and $\mathrm{H} 2$ were supported. In terms of explanatory power, the inclusion of those two variables in Step 2 had explained 30 percent of the variance in the dependent variable. The result confirmed that formal mentoring and informal mentoring acted as a major predictor of psychosocial support. Specifically, different standardized beta values between informal mentoring and formal mentoring showed that the effect of formal mentoring on psychosocial support was greater than the effect of informal mentoring on psychosocial support in the studied organization.

\begin{tabular}{|c|c|c|}
\hline \multirow{2}{*}{ Variable } & \multicolumn{2}{|c|}{ Dependent variable } \\
\hline & Step 1 & Step 2 \\
\hline \multicolumn{3}{|l|}{ Controlling Variables } \\
\hline Gender & 0.11 & 0.08 \\
\hline Supervisor's Gender & 0.16 & 0.09 \\
\hline Age & $-0.27 *$ & -0.20 \\
\hline Academic Qualification & 0.03 & 0.09 \\
\hline Length of Service & $0.28^{*}$ & 0.15 \\
\hline Position & 0.06 & 0.10 \\
\hline Division & -0.15 & -0.16 \\
\hline \multicolumn{3}{|l|}{ Independent Variable } \\
\hline Formal Mentoring & & $0.39 * * *$ \\
\hline Informal Mentoring & & 0.18* \\
\hline $\mathrm{R}^{2}$ & 0.09 & 0.30 \\
\hline Adjusted $\mathrm{R}^{2}$ & 0.05 & 0.26 \\
\hline $\mathrm{R}^{2}$ Change & 0.09 & 0.21 \\
\hline $\mathrm{F}$ & 2.02 & $6.81 * * *$ \\
\hline F Change $\mathrm{R}^{2}$ & 2.02 & $21.60 * * *$ \\
\hline
\end{tabular}

Note: Significant at $* 0.05 ; * * 0.01 ; * * * 0.001$

Table 5. "Result for stepwise regression analysis for psychosocial support as dependent variable". Source: authors

Table 6 shows that the demographic variables were entered in Step 1 and then followed by entering the independent variable in Step 2. In the analysis, career development was used as the dependent variable. An examination of multicollinearity in the coefficients table showed that the tolerance value for the relationship between formal mentoring and career development was 0.91 , and the tolerance value for the relationship between informal mentoring and career development was 0.97 . The tolerance values were more than the established 
tolerance value of 0.20 (as a rule of thumb), indicating the variables were not affected by multicollinearity problems (Fox, 1991; Tabachnick et al., 2001).

Thus, Table 6 showed the results of regression analysis that were summarized in the two steps. In step 1, age was found to be a significant predictor of career development ( $B=-0.27, p<0.05$ ), accounting for 7 percent of the variance in the dependent variable. Step 2 showed that the formal mentoring was also positively and significantly correlated with career development ( $\beta=0.27, p<0.001)$, and informal mentoring positively and significantly correlated with career development ( $\beta=0.39, p<0.001$ ), therefore $\mathrm{H} 3$ and $\mathrm{H} 4$ were supported. In terms of explanatory power, the inclusion of those two variables in Step 2 had explained 35 percent of the variance in the dependent variable.

The result confirmed that formal mentoring and informal mentoring acted as major predictors of career development. Specifically, different standardized beta values between informal mentoring and formal mentoring showed that the effect of informal mentoring on career development was greater than effect of formal mentoring on career development in the studied organization.

\begin{tabular}{|c|c|c|}
\hline \multirow{2}{*}{ Variable } & \multicolumn{2}{|c|}{ Dependent variable } \\
\hline & Step 1 & Step 2 \\
\hline \multicolumn{3}{|l|}{ Controlling Variables } \\
\hline Gender & 0.08 & 0.06 \\
\hline Supervisor's Gender & 0.12 & 0.06 \\
\hline Age & $-0.27 *$ & -0.18 \\
\hline Academic Qualification & 0.00 & 0.05 \\
\hline Length of Service & 0.23 & 0.09 \\
\hline Position & 0.01 & 0.05 \\
\hline Division & -0.03 & -0.06 \\
\hline \multicolumn{3}{|l|}{ Independent Variable } \\
\hline Formal Mentoring & & $0.27 * * *$ \\
\hline Informal Mentoring & & $0.39 * * *$ \\
\hline $\mathrm{R}^{2}$ & 0.07 & 0.35 \\
\hline Adjusted $\mathrm{R}^{2}$ & 0.03 & 0.31 \\
\hline $\mathrm{R}^{2}$ Change & 0.07 & 0.27 \\
\hline $\mathrm{F}$ & 1.61 & $8.41 * * *$ \\
\hline 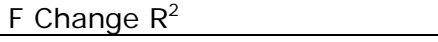 & 1.61 & $29.95 * * *$ \\
\hline
\end{tabular}

Note: Significant at $* 0.05 ; * * 0.01 ; * * * 0.001$

Table 6. "Result for stepwise regression analysis for career development as dependent variable". Source: authors

\section{Discussion and implications}

The current study confirmed that mentoring programs acted as a predictor or antecedent of individuals' advancement in the studied organization. In terms of 
different standardized beta values between informal mentoring and formal mentoring showed that the effect of formal mentoring on psychosocial support was greater than the effect of informal mentoring, while the effect of informal mentoring on career development was greater than the effect of formal mentoring in the selected organization. In the organizational context, formal and informal mentoring programs were judicially executed according to the university's policy and procedures. The majority of employees perceived that formal and informal mentoring activities had been properly implemented. As a result, it may lead to higher individuals' psychosocial support and career development in the studied organization.

The implications of this study can be divided into three categories: theoretical contribution, robustness of research methodology and practical contribution. In terms of theoretical contribution, the findings of this study showed that properly implemented informal and formal mentoring activities had created a conducive organizational climate, such as communication openness, knowledge sharing and active participation styles in planning and managing organizational functions, such as human resource (HR), finance, academic program, and physical facilities. Consequently, it may lead to increased individuals' career development and psychosocial support in the organization.

Although this study was conducted in a situation that differed from that in Western countries, its outcome has consistently supported and recognized the significance of mentoring styles in organizational mentoring programs as similar to the findings in the literature published in those countries (Khian Jui et al., 2009; Okurame \& Balogun, 2005; Niehoff, 2006).

With respect to the robustness of the research methodology, the data gathered from mentoring research literature, the in-depth interviews, the pilot study and the survey questionnaire have all exceeded the minimum standard of validity and reliability analysis. This situation may lead to the production of accurate and reliable findings.

In terms of practical contributions, the findings of this study can be used as a guideline by the management to improve the design and administration of mentoring programs in the same organization or in other organizations. The suggestions are: first, update learning content and method. For example, 
continuous training programs should focus on up-to-date knowledge, relevant skills and good moral values. If these training programs are properly implemented through oral skills and team based training methods they can upgrade the capability of mentors to use proper treatments in handling mentees' needs and expectations.

Second, encourage informal and formal participation styles. For example, mentees should be allowed to provide suggestions, comments and take part in planning and managing mentoring activities. If this aspect is given due attention then it will increase mentees' feelings of satisfaction, trust and acceptance about the programs.

Third, improve mentoring activities. For example, mentoring activities should be varied to cater to mentees' needs and preferences, such as sports and camping. Willingness of mentors and mentees to properly implement such activities after office hours and outside office may strengthen brotherhood, accountability and job motivation in the workplace.

Fourth, record formal and informal mentoring activities in log books and the information stated therein may be accounted for determining yearly performance appraisal ratings. If these suggestions are seriously considered then they may increase the capability of formal and informal mentoring programs to improve employees' advancement in organizations.

\section{Limitations and suggestions for future research}

This study used a cross-sectional design as the main procedure to collect data during the duration of this study. Therefore, it did not capture the developmental issues such as intra-individual change and restrictions of making inference to participants and/or causal connections between variables of interest. Besides that, the translation of the survey instrument into the Malay language was one of the challenges encountered by the researchers during the study. Moreover, this study was based on self-reported data, taking only perspectives of employees. Further research is needed taking into consideration the perspectives of other employees within the organization to minimize the limitations of self-reported data. In addition, this study included only two outcome variables that could correlate significantly with each other. In this sense, focusing on alternative outcome 
variables such as employee job performance, job commitment and loyalty might be an alternative way to shed light on the relationships between mentoring program activities and individual behavioral outcomes.

This research may be replicated in different organizational context and work environments. In other words, applying the research design to other professions and cross-company comparison is another recommendation for future research to generalize the applicability of the dimensions of the mentoring programs in the Malaysian context. Finally, a different approach, such as an in depth qualitative study, is advised especially when focusing on specific variables.

\section{Conclusion}

The findings of this study demonstrate that a mentoring program acts as an effective predicting variable of individual advancement in the organizational sample. This result has supported previous studies and extended mentoring research literature mostly published in Western organizational settings. Therefore, current research and practice within mentoring program models need to consider mentoring type as a critical aspect of organizational mentoring program where properly implemented informal and formal mentoring activities may strongly increase positive subsequent attitudinal and behavioural outcomes (e.g., career development, psychosocial support, work satisfaction, employee commitment, job performance, trust, and ethics). Thus, these positive outcomes may lead to sustained and supported organizational strategic vision and mission.

In sum, this study has shown that the availablity of mentoring programs have been positively linked to career development and psychosocial suppport of the employees in the sampled organization.

\section{References}

Ainsworth, M. D. S., Blehar, M., Waters, E., \& Wall, S. (1978). Patterns of attachment. Hillsdale, NJ: Lawrence Erlbaum.

Allen, T. D., \& Eby, L. T. (2004). Factors related to mentor reports of mentoring functions provided: Gender and relational characteristics. Sex Roles, 50(1/2), 129-139. 
Allen, T. D., Day, R., \& Lentz, E. (2005). The role of interpersonal comfort in mentoring relationships. J ournal of Career Development, 31(3), 155-169.

Anderson, E. M., \& Shannon, A. L. (1988). Toward a conceptualization of mentoring. J ournal of Teacher Education, 39(1), 38-42.

Bahniuk, M. H., \& Hill, S. K. (1998). Promoting career success through mentoring. Review of Business, 19 (3), 4-7.

Baron, R. M, \& Kenny, D. A (1986). This moderator-mediator variable distinction in social psychological research: Conceptual, strategic, and statistical considerations. Journal of Personality and Social Psychology, 51(6), 1173-1182.

Baugh, S. G., \& Scandura, T. A. (1999). The effect of multiple mentors on protégé attitudes the work setting. Journal of Social Behavior and Personality, 14(4) 503522.

Berscheid, E. (1994). Interpersonal relationships. Annual Review of Psychology, 45, 79-129.

Bisk, L. (2002). Formal entrepreneurial mentoring: The efficacy of third party managed program. Career Development International, (7/5), 262-270.

Blake-Beard, S. D. (2001). Talking a hard look at formal mentoring programs: A consideration of potential challenges facing women. Journal of Management Development, 20 (4), 331-345.

Bowlby, J. (1969). Attachment and loss: Vol. 1. Attachment. New York: Basic Books.

Byrne, D., \& Griffitt, W. (1973). Interpersonal attraction. Annual Review of Psychology, 24, 317-336.

Chao, G. T., Walz, P. M., \& Gardner, P. D. (1992). Formal and informal mentorships: A comparison on mentoring functions and contrast with non mentored counterparts. Personnel Psychology, 45, 619-636.

Cresswell, J. W. (1998). Qualitative inquiry and research design: Choosing among five traditions. London: SAGE publications. 
Cummings, T. G., \& Worley, C. G. (2009). Organization Development \& Change. (9th Ed.). Masan: South-Western Cengage Learning.

Dansky, K. H. (1996). The effect of group mentoring on career outcomes. Group and organizational management, 21, 5-12.

Dennison, S. (2000). A win-win peer mentoring guidebook: A practical manual for designing and managing a mentoring program.Clemson, SC: National Droput Prevention Center.

Dreher, G. E, \& Cox, T. H., Jr. (1996). Race, gender, and opportunity: A study of compensation attainment and the establishment of mentoring relationships. Journal of Applied Psychology, 8, 297-308.

Edlind, E. P., \& Haensly, P. A. (1985). Gifts of mentorship. Gifted Child Quarterly, 29 92), 55-60.

Foster, D. P, Stine, B., \& Waterman, R. (1998). Business Analysis Using Regression: A Casebook, Springer-Verlag.

Fox, J. (1991). Regression diagnostics. Thousand Oaks, CA: Sage Publications.

Friday, E., \& Friday, S. S. (2002). Formal mentoring: Is there a strategic fit? Management Decision, 40 (2), 152-157.

Goldstein, I. L., \& Ford, J. K. (2002). Training in organizations. Wadsworth: Thomson Learning.

Gregson, K. (1994). Mentoring. Employee Counseling Today, 6 (4), 26-7.

Hair, J. F., Anderson, R. E., Tatham, R. L., \& Black, W. C. (1998). Multivariate Data Analysis ( $5^{\text {th }}$ ed.). New J ersey: Prentice Hall International.

Hansford, B., \& Ehrich, L. C. (2006). The principalship: How significant is mentoring? J ournal of Educational Administration, 44(1), 36-52.

Hansford, B., Tennent, L., \& Ehrich, L. (2003). Educational mentoring: Is it worth the effort? Educational Research \& Perspectives, 30(1), 42-75. 
Hansman, C. A. (2000). Formal Mentoring Programs In Handbook of Adult and Continuing Education, American Association for Adult and Continuing Education, San Francisco: Jossey-Bass.

Hegstad, C. D., \& Wentling, R. M. (2005). Organizational antecedents and moderators that impact on the effectiveness of exemplary formal mentoring programs in fortune 500 companies in the United States. Human Resource Development International, 8(4), 467-487.

Hawkey, K. (1997). Roles, responsibilities, and relationships in mentoring: A literature

Hulland, J. (1999). Use of partial least square (PLS) in strategic management research: A review of four recent studies. Strategic Management J ournal, 20 (2), 195-204.

Hunt, D.M., \& Michael, C. (1983). Mentoring a career training and developing tool. Academy of Management Review, 8, 475-85.

Ismail, A., Khian Jui, M. K., \& Abdullah, M. M. (2009). Formal Mentoring, Gender Type in Mentorship and Individuals' Psychosocial: A Moderating Model Approach. Pakistan J ournal of Commerce and Social Sciences, 2, 10-24.

Irving, E. S., Moore, W. D., \& Hamilton, R. J., (2003). Mentoring for high ability school students. Education and Training, 45(2), 100-109.

Jaccard, J., Turrisi, R., \& Wan, C.K. (1990). Interaction effects in multiple regression, 72. Newsbury Park, California: SAGE Publications, Inc.

Johnson, S. K., Geroy, G. D., \& Griego, O. V. (1991). The mentoring model theory: dimensions in mentoring protocols. Career Development International, 4(7), 384391.

Khian Jui, M. K. (2008). The relationship between mentoring types and individuals' advancement: Gender differences in mentorship as a moderator. Unpublished Final Year Project Report. Universiti Malaysia Sarawak, Malaysia.

Khian Jui, M. K., Ismail, A. \& Yaacob, M. R. (2009). Relationship between formal mentoring and individuals' advancement: The moderating role of gender type. 
The paper was published in the $1^{\text {st }}$ International Conference on HCD (ICONHCD's 09), May 25-27, 2009, Universiti Malaysia Pahang, Malaysia.

Kram, K. E. (1985). Mentoring at work: Developmental relationships in organizational life. Glenview, IL: Scott Foresman.

Kram, K. E. (1988). Mentoring at work. ( $2^{\text {nd }}$ ed.). Lanham, Md: University Press of America.

Kram, K. E., \& Bragar, M. C. (1991). Career development through mentoring. A strategic approach for the 1990s. Mentoring International, 5, 1-2.

Levesque, L. L., O'Neill, R. M., Nelson, T., \& Dumas, C. (2005). Sex differences in the perceived importance of mentoring functions. Career Development International, 10(6/7), 429-443.

Levinson, D. J., Darrow, C. N., Klein, E. B., Levinson, M. H. \& McKee, B. (1978). Seasons of a man's life. Englewood Cliffs, NJ: Prentice-Hall.

Lindenberger, J. G., \& Zachary, L. J. (1999). Play "20 Questions" to develop a successful mentoring program. Training \& Development, 53 (2), 12-14.

Long, S. (2002). Mentoring: A personal reflection. New Library World, 103 (1174), 94-97.

Lyon, J. M., Farrington, P., \& Westbrook, J. (2004). Mentoring of scientists and engineers: A Comparison of gender. Engineering Management Journal, 16(3), 1725.

Merriam, S. (1993). Mentors and proteges: A critical review of the literature. Adult Education Quarterly, 33 (3), 161-73.

Murray, M. (1991). Beyond the myths and magic of mentoring: How to facilitate an effective mentoring program. San Francisco, CA: Jossey-Bass.

Niehoff, B. P. (2006). Personality predictors of participant as a mentor. Career Development International, 11(4), 321-333.

Noe, R. A. (1988). An investigation of the determinants of successful assigned mentoring relationships. Personnel Psychology, 41(3), 457-479. 
Noe, R. A., Greenberger, D. B., \& Wang, S. (2002). Mentoring: What we know and where we might go. New York: Elsevier Science.

Northcott, N. (2000). Mentoring in nursing. Nursing Management, 7 (3), 30-2.

Nunally, J. C. \& Bernstein, I. H. (1994). Psychometric Theory. New York: McGraw Hill.

Okurame, D. E., \& Balogun, S. K. (2005). Role of informal mentoring in the career success of first-line bank managers. Career Development International, 10(6/7), 512-521.

Oliver C., \& Aggleton, P. (2002). Mentoring For Professional Development in Health Promotion: A Review of Issues Raised By Recent Research, Institute Of Education, UK. Universiti of London. 102 (1), 30-38.

Ragins, B. R. (1997). Diversified mentoring relationships in organizations: A power perspective. Academy of Management Review, 22, 482-521.

Ragins, B. R. (1999). Gender and mentoring relationships. Thousand Oaks, CA: Sage.

Ragins, B. R., \& Cotton, J. L. (1993). Gender and willingness to mentor in organizations. Journal of Management, 19, 97-111.

Ragins, B. R., \& Cotton, J. L. (1999). Mentor functions and outcomes: A comparison of men and women in formal and informal mentoring relationships. Journal of Applied Psychology, 84, 529-550.

Ragins, B. R., Cotton, J. L., \& Miller, J. S. (2000). Marginal mentoring: The effects of type of mentor, quality of relationship, and program design on work and career outcomes. Academy of Management Journal, 43, 1177-1194.

Ritchie, N., \& Connolly, M. (1993). Mentoring in public sector management: Confronting accountability and control. Management Education and Development, 24 (3), 253-71.

Ritchie, A., \& Genoni, P. (1999). Mentoring in professional associations: Continuing professional development for librarians. Health Libraries Review, 16, 216-225. 
Russell, J. E. A., \& Adams, D. M. (1997). The changing nature of mentoring in organizations: An introduction to the special issue on mentoring in organizations. J ournal of Vocational Behavior, 51, 1-14.

Scandura, T. A. (1992). Mentorship and career mobility: An empirical investigation. J ournal of Organizational Behavior, 13, 169-174.

Sekaran, U. (2000). Research methods for business: A skill building approach. New York: J ohn Wiley \& Sins, Inc.

Sprecher, S. (1998). Insiders' perspectives on reasons for attraction to a close other. Social Psychology Quarterly, 61, 287-300.

Tabachnick, B. G., Barbara, G., \& Fidell, L. S. (2001). Using multivariate statistics. Sydney: Allyn \& Bacon.

Turban, D. B., Dougherty, T. W., \& Lee, F. K. (2002). Gender, race and perceived similarity effects in developmental relationships: The moderating role of relationship duration. Journal of Vocational Behavior, 61, 240-262.

Van Maanen, J. (1983). Qualitative methodology. Beverly Hills, CA: SAGE Publications.

Wanguri, D. M. (1996).Diversity, perceptions of equity, and communicative openness in the workplace. The Journal of Business Communication, 33 (4), 44357.

Waters, L. (2004). Prote'ge'-mentor agreement about the provision of psychosocial support: The mentoring relationship, personality, and workload. Journal of Vocational Behavior, 65, 519-352.

Yaacob, M. R. (2008). SPSS for business and social science students. Pustaka Aman Press Sdn. Bhd. Malaysia.

Young, A. M., Cady, S., \& Foxon, M. J. (2006). Demystifying gender type in mentoring: Theoretical perspectives and challenges for future research on gender and mentoring. Human Resource Development Review, 5(2), 148-175. 
Article's contents are provided on a Attribution-Non Commercial 3.0 Creative commons license. Readers are allowed to copy, distribute and communicate article's contents, provided the author's and Journal of Industrial Engineering and Management's names are included. It must not be used for commercial purposes. To see the complete license contents, please visit http://creativecommons.org/licenses/by-nc/3.0/. 